\title{
A IMPESSOALIDADE DA EDUCAÇÃO BURGUESA: SENTIDO E GÊNESE*
}

\author{
Ged Guimarães**
}

\section{RESUMO}

Neste artigo, procura-se demonstrar a diferença de sentido do processo de formação que a sociedade de corte e a sociedade burguesa produzem. Parte-se do princípio de que os fundamentos da modernidade pedagógica são constituídos na sociedade de corte. $\mathrm{O}$ que as relações burguesas alteraram, no que diz respeito à educação, foram os pressupostos pessoais de apreço, estima e consideração ao hierarquicamente superior, para a impessoalidade própria de seus princípios constitutivos.

Palavras-chave: educação; sociedade de corte; sociedade burguesa.

As cidades, embora não tenham origem uniforme em tempos e lugares e contarem com uma reduzidíssima população - cerca de $15 \%$ na França, no ano da grande revolução -, já se constituíam, no século $\mathrm{XV}$, em lugares onde se experimentava um novo modo de vida, tendo como fundamento a liberdade. ${ }^{1}$ Elas ofereciam outra possibilidade de vida, cuja condição para ser cavalheiro não se reduzia, tão-somente, à extensão da propriedade de terras, mas também à boa etiqueta. É, pois, na cidade que surge uma nova camada de trabalhadores. São "homens que, na cidade, nos bairros em constante expansão, trabalham a lã, o couro e os metais, que vendiam belos tecidos, bem como jóias, e corriam de feira em feira em caravana" (Duby, 1988, p. 59). As cidades propiciam um novo espetáculo diferente de todos vividos até então. Vejamos a esse respeito o que diz ainda Duby:

\footnotetext{
* Artigo recebido em 21/05/2005 e aprovado em 5/07/2005.

** Doutor em educação pela UFMG e professor de filosofia da educação da Faculdade de Educação da UFG. E-mail: guimarz@zipmail.com.Br
} 
As cidades, contudo, querem-se separadas da área rural. O burguês despreza os camponeses. E também os teme. Entrincheira-se contra eles. A cidade é um lugar protegido, com portas que se fecham cuidadosamente à noite, com muralhas que se modernizam com esses rápidos aperfeiçoamentos que favorecem a arquitetura militar tanto quanto a das igrejas. [...] A cidade é cidadela, porque as riquezas que ela contém são tentadoras, fáceis de tomar, pois os que entre esses muros detêm o poder sabem que ali é o lugar dos melhores ganhos e que é preciso proteger esse recurso: a primeira preocupação do rei Felipe Augusto foi a de fortificar Paris, de onde lhe vinha a parte mais segura de suas rendas monetárias. E, quando São Luís, seu neto, fundou Aigues-Mortes na orla mediterrânea do seu domínio, a fim de embarcar com mais facilidade para a Terra Santa, primeiro mandou construir uma muralha em torno desse ponto de apoio onde se amontoavam as provisões. [...] Tão ciosamente guardadas quanto as outras, essas fortalezas que são as cidades se distinguem pelo fato de estarem abertas para o tráfico. Vivem dele. Guerreiros e padres residem ali, mas são os homens de negócios que lhes garantem a prosperidade e por vezes as governam sozinhos. (DuBY, 1988, p. 60)

Mas o que caracteriza a cidade e a faz diferente de todas as outras já construídas pelos homens é que nela "concentra-se o mais vivo da animação, [...] daquilo que se descobre pelo estudo e pelo artifício, daquilo que se troca e daquilo que os comboios trazem das aldeias dos arrebaldes" (DuBY, 1988, p. 61).

Ao mesmo tempo em que a norma vai sendo subvertida por pessoas de origem e objetivos diversos, um deslocamento do lugar da norma, por assim dizer, está se processando. Mas, afinal, como era esse lugar e como se dava a sua representação? É o que vamos discutir em seguida.

A sociedade de corte, na modernidade, assume o lugar do poder político em um momento em que havia ausência de uma força central reguladora: os senhores feudais já não conseguiam impor-se como força preponderante, os reis e príncipes estavam desprovidos de armas e respeito, e a Igreja Católica não era mais a única instituição que falava em nome da fé. Esse período - aquele compreendido entre os séculos XV e XVIII - vive, indubitavelmente, um fecundo espírito de transformação sentido especialmente nas cidades que renasciam em importância econômica e política. 
É certo que em nenhum momento essas forças foram unânimes. O que se destaca é que, na modernidade, as contradições se afloram, revelando uma espécie de crise de autoridade, lentamente superada pela presença da corte, que, diferentemente da realeza dos impérios anteriores, marcados pela expansão bélica, assume função normalizadora.

Antes da corte estabelecer-se com novas atribuições, especialmente a partir do Renascimento, ${ }^{2}$ só a espada definia o lugar do poder isso não era menos verdadeiro para o duelo entre os indivíduos, que para a guerra entre os povos. Sem ela - nas relações feudais já enfraquecidas - os saques, as invasões, as disputas individuais por um dado bem, ou em defesa da honra, eram resolvidos pelo sangue. Com a corte renovada, ela assume o lugar do sangue. Renato Janine, a esse respeito, diz:

Há menos espaço para as razias e pilhagens, que agora necessitam, o mais das vezes, da sanção de um príncipe ou da igreja. Nesse contexto, a guerra vai tornar-se assunto de Estado e os cavaleiros lutarão a mando de seu príncipe, não só por seu gosto próprio. (RIBEIRO, 1999, p. 32)

Bem mais que uma força bruta reguladora como ato individual ou expressão de um monarca, a força - enquanto honra lavada a sangue transfere-se para as opiniões públicas e os corações dos homens. E se o monarca tem força, ele a possui "em nome da paz nos seus domínios, em defesa da justiça que seus tribunais ministram, punem de morte quem tire satisfações pela espada" (RIBEIRo, p. 40-41).

Ora, o novo monarca também é moderno. Se ele chama para si o controle, ele o faz em nome de um universo social mais complexo: agora há comerciantes, banqueiros, artesãos. Em uma só expressão, novos ricos, para os quais o poder real abre o leque. Para esses novos ricos, definitivamente, não é a espada, mas o empreendimento e a decorrente riqueza, o critério para o melhor lugar na sociedade, definido pelo privilégio na hierarquia da corte. Quando os reis de Portugal e da Espanha patrocinaram todo o conjunto que resultou nos descobrimentos marítimos, esses empreendedores, presentes em vários países europeus, em certa medida, saem beneficiados. Eles crescem em condições econômicas, ampliam o poder na sociedade, conquistam privilégios junto ao rei e ganham dele títulos de nobre que, de início, segundo a concepção instituída na corte, era justo porque o prêmio atribuído ao rico era só mais um ao 
lado do título de nobreza conferido ao valente, ao sábio, ao amigo, mas "terminará posta à venda: Jaime I da Inglaterra, em 1611, para obter fundos, cria uma nova categoria nobiliárquica (os baronetes), fixa em duzentos o seu número e passa a vender os diplomas" (Ribeiro, p. 36).

Antes de chegar à trágica consequiência - para o monarca - dessa queda mercadológica da venda dos títulos - pois os desvalorizava porque a sua origem não era pela honra, mas pela compra -, um longo e dinâmico processo se estabelece: "o mérito renova a aristocracia, mas sob o controle do rei que assim reforça o seu poder; já a hereditariedade preserva os nobres, velhos e novos, de um excessivo poder régio" (RibeIRo, p. 37).

Ainda segundo Ribeiro, será na etiqueta "o meio pelo qual os reis vão domesticar a honra, fazendo-a fluir do trono em vez da iniciativa individual. É no sorriso de Luís XIV, mais que na espada de duelistas, que o nobre vai se sentir honrado" (RIBEIRO, p. 40). O poder do rei não se define mais, tão-somente, pela grandiosidade do império, pela força das armas, pela pompa do castelo ou pela benção do papa. Era pela etiqueta, tendo no rei ou na rainha sua maior expressão, que a sociedade hierarquizava-se. O critério era o privilégio: quanto mais próximo do rei mais considerado, quanto mais longe, menos.

A prática da etiqueta consiste [...] numa auto-representação da sociedade de corte. Através dela, cada indivíduo, e antes de todos o rei, tem o seu prestígio e a sua posição de poder relativa confirmados pelos outros. A opinião social que forja o prestígio dos indivíduos se expressa através do comportamento de cada um em relação ao outro, dentro de um desempenho conjunto que segue determinadas regras. Ao mesmo tempo, nesse desempenho conjunto, torna-se visível imediatamente, portanto, o vínculo existencial entre os homens singulares a sociedade na corte. Sem a confirmação de seu prestígio por meio do comportamento, esse prestígio não é nada. A importância conferida à demonstração de prestígio, à observância da etiqueta, não diz respeito a meras "formalidades", mas sim ao que é mais necessário e vital para a identidade individual de um cortesão. (Elias, 2001,p. 117-118)

Na verdade, a corte comportava uma maior diversidade social. É certo que a origem nobre do indivíduo constituía, por si, uma condição privilegiada. Mas, note-se bem, quando se confere importância à etiqueta, que deixa de ser tão-somente meras formalidades da corte, para serem 
vitais, a formação para tal sociedade torna-se necessária. Segundo Norbert Elias,

Só nessa sociedade de corte eles podiam manter aquilo que dava sentido e rumo a suas vidas: sua existência social como membros da corte, a distância em relação ao comum dos mortais, o prestígio - a imagem central que fazia de si próprios, sua identidade pessoal. Eles não freqüentavam a corte apenas porque dependiam do rei, mas permaneciam dependentes do rei porque só pelo acesso e à vida junto à sociedade de corte podiam manter a distância em relação aos outros, distância da qual dependia a salvação de suas almas, de seu prestígio como aristocratas de corte, ou seja, de sua existência social e sua identidade pessoal. (2001, p. 116)

As relações sociais comportam uma hierarquia na qual a etiqueta é o centro. Ela torna-se, por assim dizer, em um ideal a ser conquistado, tanto por nobres quanto por aspirantes a títulos de nobreza. No mínimo, o gesto de acordar, levantar, comer, beber, dormir etc. compõe-se de signos que se espetacularizam e seduzem. A esse ritual, o rei, ao mesmo tempo em que era o protagonista, a ele também se submetia. O público desejava assistir e participar. Quem estava próximo do rei sentia orgulho $\mathrm{e}$, ao mesmo tempo, era invejado pelo inferior. $\mathrm{O}$ grande objetivo era conquistar um lugar imediatamente superior na hierarquia ou, ao menos, assegurá-lo. Para esse fim, um longo e minucioso ritual era estabelecido, o que fazia uma espécie de cortejo imanente e transcendental do rei. Vejamos a esse respeito o que diz Renato Janine Ribeiro:

O levantar-se e o deitar do rei são cerimônias mais importantes da liturgia real. Até Saint-Simon, homem inteligente e que terminará detestando Luís XIV, fica feliz se o rei o incumbe de segurar o castiçal quando vai deitar-se. Vejamos como ele se levanta: Às oito horas da manhã, se não fixou outro momento, Luís é acordado pelo primeiro criado de quarto, que dorme ao pé de seu leito. As portas abrem-se, quando o rei já está de peruca, deixando entrar os pajens; uns vão servi-lo, outros correm a chamar os primeiros cortesãos, já à espera no corredor. $\mathrm{O}$ acesso obedece a estrita hierarquia; a partir deste momento se contam seis diferentes entradas. A primeira é a "entrada da família": além dos filhos e netos legítimos de reis (os "enfants de France"), entram os príncipes e princesas de sangue, mais alguns cortesãos que servem o rei no trajar-se e em sua saúde. Depois vem a 
"grande entrada", a dos príncipes oficiais do quarto e do guardaroupa, além de alguns nobres especialmente convidados. [...] Enquanto isso, Luís deixa a cama; vem então a "primeira entrada", com os leitores do rei, o intendente dos prazeres e festividades, $\mathrm{e}$ alguns outros. Depois de calçar-se, o rei permite a "entrada do quarto" aos outros oficiais do quarto, ao esmoler-mor, aos ministros e secretários de Estado, aos marechais de França etc. Dois cortesãos ajudam Luís a trocar de roupa, atam-lhe os sapatos, prendem-lhe a espada. Vem então a Quinta entrada, mais arbitrária: dela participam os nobres admitidos pelo camareiro-mor com o aval do rei. Até aqui, as entradas vieram declinando de importância; mas a Sexta e última inverte este processo, porque é a mais cobiçada: os escolhidos não vão apenas ver o rei, também se dão a ver aos cortesãos já reunidos no quarto. É a vez dos filhos do rei, legítimos e bastardos, com suas famílias, e do poderoso "superintendente das construções" (um dos cargos de Colbert); em vez de virem do corredor e entrarem pelas portas maiores, usam uma porta traseira, mais íntima. O rei, que já rezou, sai então aos corredores, onde toda a corte se dispõe à sua espera. Gestos mais triviais adquirem uma importância que, somada ao fascínio que exercem, serve a organizar a hierarquia da corte. (1999, p. 44-45)

Note-se, pois, que a etiqueta é mais que formalidade. É, na verdade, expressão da hierarquia que ensina a cada um o seu lugar. Talvez, mais que isso, ensina que a existência real é aquela que todos devem admirar, cortejar e, de certa forma, almejar. Trata-se, pois, da existência do rei. Só ele, que foi abençoado, é verdadeiro. Desse modo, desejar um lugar mais próximo possível ao rei significava poder gozar de quase todos os privilégios a ele conferido. A respeito do privilégio nessa sociedade diz Norbert Elias:

Quem tinha o privilégio de participar da primeira entrée, ou de entregar a camisa ao rei, olhava com desprezo uma pessoa que só tinha o direito à terceira entrée e não queria lhe ceder o lugar. O príncipe não queria ceder o seu lugar ao duque, que não queria ceder o seu ao marquês, e todos eles juntos, constituindo a noblesse, não queriam e nem podiam ceder seu lugar àqueles que não eram nobres e tinham de pagar impostos. Uma atitude alimentava a outra; assim graças ao fenômeno da pressão e contrapressão, a engrenagem social se equilibrava, estabilizando-se em uma espécie de equilíbrio estável. Era na etiqueta que esse estado de equilíbrio se expressava aos olhos 
de todos. Para quem estava envolvido, ela significava uma garantia precária, é verdade - de sua existência social e de seu prestígio. (2001, p. 105)

O gesto, simples exposição do rei com sua indumentária, expressa a etiqueta à qual se curvam não só as pessoas concretamente, mas compõe o imaginário: sonham em ver o rei, desejam tocar no rei. Ora, quem tem essa possibilidade, mesmo que esteja reduzido a uma total servidão, sente orgulho. Os nobres sentem-se como ele e, em certa medida, agem como ele. Não por acaso, a burguesia emergente compra títulos de nobreza. Note-se, pois, que na corte a racionalidade não é política e nem está voltada para a organização da lógica da fé, embora ambos constituam parte da vida dos homens individualmente e da sociedade em seu conjunto. Nessa sociedade, a racionalidade volta-se para a anatomia da hierarquia, ou seja, para o

lugar que o indivíduo ocupa na hierarquia [...] naquele momento. A ascensão ou a queda em tal hierarquia - continua Norbert Elias significava tanto para os cortesãos quanto o ganho ou a perda do comerciante em seus negócios. E o pavor de um cortesão ante a ameaça de declínio de sua posição e de seu prestígio não era menor do que o pavor de um comerciante ante a ameaça de perda do capital ou de um administrador ou funcionário ante a ameaça de perder seus cargos. (RIBEIRO, 1999, p. 111)

Estamos, pois, diante de relações pessoais. Se o lugar do outro era almejado, havia necessidade de parecer igual ou melhor que ele. Daí, o esmero na etiqueta que se constituía, ao lado da riqueza material, tanto em condição de garantia do lugar na hierarquia quanto condição para um posto mais alto ou mais próximo do rei. Falava-se diretamente a homens definidos em um lugar e portadores de um valor conferido pelo título. Para Norbert Elias,

pisamos em solo mais firme quando o ponto de partida não são muitos indivíduos singulares, mas a figuração que formam entre si. A partir dessa perspectiva, não é difícil entender a perfeita conveniência das atitudes, o cálculo preciso dos gestos, a nuance das palavras, em suma, a forma de específica racionalidade que se tornou uma espécie de segunda natureza dos membros dessa sociedade. Eles sabiam exercer essa racionalidade sem esforço, com elegância - e de fato ela 
era indispensável -, assim como instrumentos da disputa na concorrência por prestígio e status. (2001, p. 110)

Mas a sociedade de corte constituída e constituinte da etiqueta, sendo o rei a expressão dela, passa a conviver com outro valor: trata-se do privilégio - conquistado inclusive junto ao rei - originado da riqueza mercante. Valor que, lentamente, ganha consideração e respeito na hierarquia. Assim, aquele que tem mais recursos acaba conquistando bons títulos na sociedade, o que resulta na alteração dela, porque traz para o seu interior interesses antagônicos aos princípios da sociedade de corte, pois, enquanto ela funda-se no privilégio, os burgueses, com suas relações mercantis, na capacidade empreendedora. Para estes o que interessa é a racionalidade econômica; para aqueles - os nobres da corte - é, por assim dizer, a bajulação que determina a norma. Norbert Elias, a esse respeito, lembra Saint-Simon, nos seguintes termos:

$\mathrm{Na}$ corte o assunto nunca era a coisa, mas sim o que ela significava para determinadas pessoas. Novamente mostra-se o sentido que a etiqueta e o cerimonial tinham para a nobreza de corte. É natural que esse mecanismo nos pareça sem sentido, pois sua motivação objetiva nos escapa - uma utilidade ou intenção a que ela se refira - e tendemos a observar todas as pessoas a partir de sua função prática. Porém, como vemos, a sociedade de corte enfatizava justamente o contrário. Enquanto nós freqüentemente coisificamos e objetivamos tudo o que é pessoal, os cortesãos tinham tendência a personalizar também as coisas; pois sempre estavam interessados em primeiro lugar nas pessoas e suas inter-relações. (2001, p. 117)

As relações interpessoais, marco da sociedade de corte, como lembra Norbert Elias, apontam uma outra possibilidade para o processo de formação, pois, na relação social, o cortesão olha para o lugar daquele com quem se fala. O diálogo não era de iguais como pressupõe o princípio cristão que afirma que somos todos pecadores e, como tais, devemos buscar a remissão, mas não é, ainda, uma relação de igual por igual, em face de um objeto imanente com um determinado valor universalmente aceito, inerente ao espírito burguês. O diálogo na sociedade de corte, antes de se pautar pela crença em forças santas ou demoníacas, naturais ou teóricas, pautava-se na etiqueta que legitimava as relações de estima e consideração ao imediatamente superior na hierarquia. Estamos, pois, a meio caminho da educação prática e utilitária requerida pelo burguês. 
Referindo-se aos novos pressupostos da organização social, Norbert Elias afirma:

A racionalidade industrial, profissional e burguesa tem sua origem nas coerções das interdependências econômicas; com elas, o que se torna calculável, em primeira instância, são as chances de poder baseadas no capital privado ou público. A racionalidade de corte se constitui a partir das coerções da interdependência social das elites; ela serve para tornar calculável, em primeiro lugar, as pessoas e as chances de prestígio como instrumentos de poder. (2001, p. 127)

O que estava se processando era, na verdade, uma alteração substancial em relação ao modo de vida, tanto individual quanto social, à qual se somam as mudanças nos princípios de educação. Comênius (1977), embora esteja vinculado aos princípios cristãos, irá propor uma maior eficácia no processo de formação, visando formar em menos tempo um maior número de pessoas. ${ }^{3}$

O ideal de formação do homem vai lentamente sendo alterado. A boa etiqueta, condição para o prestígio como instrumento de poder - tanto daquele que o deseja quanto daquele que o aspira - traz a marca da impessoalidade das relações, fundadas no cálculo com finalidade lucrativa.

Quase tudo que a sociedade de corte dos séculos XVII e XVIII elaborou, seja a dança, as fórmulas de polidez, os costumes mundanos, os quadros com que enfeitam as casas, as formalidades de um pedido de casamento ou o lever de uma dama, tudo isso fica relegado agora, cada vez mais, à esfera da vida particular. Essas coisas deixaram de ocupar o centro das tendências modeladoras da sociedade. A vida particular dos burgueses certamente não permaneceu imune às coerções sociais. Todavia, ela só recebeu indiretamente sua forma, ou seja, a partir da interdependência primordial que associava os indivíduos, isto é, a condição profissional. As formas da vida profissional, no entanto, foram submetidas a exigências de uma outra ordem e com outra intensidade, em comparação com a vida privada. A vida profissional é que passou a ser objeto de todos os cálculos, sutilezas e aprimoramentos. (ELIAS, p. 130)

Note-se, pois, que é o ofício e não o privilégio que define a posição do homem na sociedade burguesa já embrionária. Se a boa etiqueta 
denotava o princípio da formação para a vida na sociedade de corte, a vida burguesa, que se afirma, volta-se para a formação do profissional. Aqui, a formação é para o valor mercantil; lá, para o privilégio. É certo que o burguês almeja uma melhor condição, o que muda é o critério para esse fim. Na corte, como dissemos, é a bajulação; na sociedade burguesa, é o ofício. Aliás, foi o próprio ofício que propiciou condições econômicas para o burguês ascender socialmente, inclusive comprando títulos nobiliários.

Paradoxalmente, a própria mercantilização, que faz enriquecer o rei e garantir a hierarquia, promove a ruína da própria nobreza, porque o "valor comercial" do título, com o tempo, oscila segundo o mercado, e o valor nobiliário banaliza-se.

Mas o burguês, sabemos, não compra só títulos. O poder que o dinheiro lhe confere propicia-lhe também condições para colocar a seu dispor o que há de melhor na sociedade no que se refere aos bens materiais e culturais. ${ }^{4}$

Tudo isso, entretanto, constituía no século XVI tão-somente um incipiente desejo do homem em ser prático e eficaz com o menor tempo possível. O indivíduo descobre-se como parte constitutiva de uma sociedade e não apenas mais um pecador em busca da remissão, ou um servo em busca de proteção. É certo que estamos longe do time is money, mas estamos em um tempo em que os princípios que lhe dão sustentação estão sendo gestados. A novidade, instituinte nesse processo, penso ser a pressa. A pólis não existe mais, e a vida eterna começa a pertencer ao "industrioso e racional" (LOCKE, 1983, p. 47). Não há algo fora do indivíduo que deva ser prioritariamente cuidado, e as boas ações passam a ser traduzidas por bons empreendimentos - já notados no século XII. Duby, a esse respeito, referindo-se às catedrais que surgem a partir de então, diz que elas são a expressão desse empreendimento. "Muitos dos vitrais" - referindo-se aos ornamentos das Igrejas - "são oferecidos pelas associações de trabalhadores, que pretendiam assim consagrar ostensivamente as primícias de sua jovem prosperidade" (DuBy, 1988, p. 59).

O empreendedor torna-se, desse modo, aquele que é útil sob o ponto de vista econômico, em três aspectos: para ele mesmo, para a vida social e para a vida religiosa. Note-se, pois, que o indivíduo agora se define por essa combinação e o ponto de partida será ele mesmo, ou seja, o empreendimento que beneficia, a curto prazo, a si mesmo. $\mathrm{O}$ critério que justifica essa possibilidade é a capacidade que todos têm, 
pois são iguais. Descartes explica essa capacidade em duas dimensões: a res-cogitam e a res-extensa. A primeira está em nós e se manifesta na vontade. ${ }^{5}$ A segunda oferece-nos os limites mas, ao mesmo tempo, a possibilidade de superá-los. A vontade, na concepção cartesiana, é o que nos aproxima de Deus, a que nos faz querer experimentar a perfeição em tudo. Entretanto, como não somos Deus e o corpo (res-extensa) é a prova indelével, aquele que nos leva ao engano, pois constituído de sentidos enganadores, somos levados a criar regras para que erremos o menos possível. Ao criar regras, o homem, na verdade, está procurando meios de vencer os limites - dados pelo corpo - em busca da verdade e fazer a vontade triunfar porque o homem tende a "idéias claras e distintas" (Descartes, 1962, p. 53).

Entre os empiristas, Bacon traça um outro caminho. Para ele, o homem é o ser que possui capacidade de experiência. Tudo que se deseja provar deve-se partir de fatos concretos até chegar às causas gerais. Bacon, para esse fim, apresenta os passos metodológicos indutivos, ou seja, as tábuas de investigação. ${ }^{6} \mathrm{~A}$ primeira é a presença. Nela procurase os elementos concordantes com as mesmas características. O segundo é a ausência, isto é, saber as razões do fenômeno contrário à presença se constituir. O terceiro é a comparação, ou seja, saber os graus da mudança para controlar a variação.

Tanto na perspectiva racionalista apresentada por Descartes quanto na empirista baconiana, a preocupação central é com o método de investigação. Ambos estão empenhados em apontar um caminho seguro que ofereça a possibilidade da verdade, a qual, segundo eles, não se atinge tão-somente pela palavra da autoridade, mas pela força de investigação segura, feita por qualquer um que tenha espírito inquiridor.

Mas para que o novo se institua, uma corrente de fatos precisa estar encadeada, e a ausência desse encadeamento faz adiar qualquer intento. A esse respeito diz Hilário Franco:

Em meados do século XI as escolas urbanas mantinham-se muito presas às influências eclesiásticas, o que limitava seu papel. Quando, naquele momento, um incêndio destruiu a escola episcopal de Gand e os burgueses aproveitaram-se para abrir suas próprias escolas, o clero protestou contra esta "insolência dos leigos". Percebendo que apenas nos quadros urbanos podia se desenvolver aquele novo tipo de profissional que é o intelectual, o clero renovava suas críticas às cidades: para o abade Ruperto de Deytz, em princípios do século XII, 
as cidades são ímpias - a primeira delas não foi construída por Caim? - e cheias de vãs discussões entre mestres e alunos. (1988, p. 140141)

A modernidade coloca o necessário encadeamento na ordem do dia e chama a educação para assumir essa responsabilidade. Ela se faz leiga, pois a intenção não é formar o bom cristão, mas o homem capaz de assumir as novas funções públicas e privadas. A escola que daí nasce é estruturada segundo a anatomia da disciplina leiga, pois precisava formar o cidadão. Note-se, pois, que a idéia de formação vem recheada de preocupações práticas.

A esse respeito diz Cambi, referindo-se ao caráter das escolas que nascem a partir do século XVII:

Nasce, assim, o sistema escolar moderno, embora de modo ainda embrionário e não totalmente desenvolvido nas suas potencialidades; todavia, as características essenciais já estão todas presentes. Já existe uma articulação entre escola elementar (que inicia nos instrumentos básicos da elaboração cultural: o alfabeto e os números), escola média ou secundária (formativa e profissional, ou melhor, formativa ou profissional), a instrução superior ou universitária que abre para as profissões superiores ou liberais. Os diversos graus não têm ainda uma gestão comum, concentrada nas mãos do Estado, mas apresentam sintomas precisos de um processo nessa direção, com a criação de escolas técnicas superiores, como as de artilharia, de engenharia etc. (1999, p. 305-306)

As escolas já se fizeram presentes no processo de formação do homem. Na Idade Média, sob a responsabilidade da Igreja Católica, elas ensinavam como ser cristão e, por decorrência, um bom servidor - tanto da Igreja quanto dos Senhores. Entre os gregos, a preocupação era formar o político. Um entusiasta moderno poderia dizer que ambas também eram práticas, justificando que os medievais vinculavam a formação às necessidades teológicas e os gregos, às necessidades políticas. Desse modo, se a formação na modernidade também é prática, o que houve foi uma substancial mudança de seu conteúdo: formar o indivíduo. Isso significa dizer que a formação de que falam os modernos volta-se para a constituição do homem, antes de mais nada, voltado para si mesmo. Em uma palavra, um indivíduo. ${ }^{7}$ 
Ariès refere-se à estrutura social arquitetada especialmente a partir do século XVI e que, por assim dizer, conclui-se no final do século XIX: é a da sociedade anônima. Para ele,

A sociedade tornou-se uma vasta população anônima onde as pessoas já não se conhecem. O trabalho, o lazer e o convívio com a família são doravante atividades separadas em compartimentos estanques. $\mathrm{O}$ homem procura proteger-se dos olhares dos outros e para isso lança mão de dois recursos: 1) o direito de escolher mais livremente (ou pensar que assim escolhe) sua condição de vida; 2) o recolhimento junto à família, transformada em refúgio, centro do espaço privado. (1981,p. 8)

O que está se processando lentamente é, de um lado, a ampliação do espaço público que se manifesta, por exemplo, na própria organização geográfica das cidades com sua arquitetura, ruas, praças, pontes, feiras, igrejas - agora bem maiores para comportar o grande público que a freqüenta. Mas, por outro lado, essa publicização faz encolher o espaço privado, fazendo o indivíduo refugiar-se na casa, espaço lentamente também invadido por um poder crescente que o captura em favor de um bem coletivo, que acredita ser melhor para ele. Esse poder é representado pelo Estado que aumenta em força à medida que encolhe o poder do indivíduo. Entretanto, a ausência desse poder, aliado à falta do indivíduo formado segundo os princípios da civilidade, seja ela nobre ou burguesa, gera inquietação, à qual duas tendências, no plano político, passam a ser defendidas. Uma diz respeito ao fortalecimento do poder central, o que significava o fortalecimento da monarquia; ${ }^{8}$ a outra confere ao povo a soberania.

Todavia, não importando de que lado pendam as questões de ordem política, o processo de formação coloca-se como tarefa de todo o conjunto social. Ele se amplia na figura do rei, ou do governante como o maior educador, e se particulariza em métodos de ensino que aparecem sob variados princípios. O Rattio Studiorum ou a didática de Comênius expressam essa preocupação infinitesimal, que ensina no detalhe como formar o homem. Ariès destaca que um dos fatores que contribuiu para a particularização do indivíduo foi a possibilidade da leitura, auxiliada pela invenção da imprensa. Com o livro, o indivíduo pode exercitar o "livre arbítrio". Ele lê, ele imagina, ele refaz, ele projeta sem o concurso 
de nenhum poder. A leitura individual, diz Ariès (1981, p. 10), "permite uma reflexão solitária que de outro modo teria sido mais difícil fora dos espaços piedosos, dos conventos ou das ermidas, equipados para a solidão". Ao lado dessa possibilidade que o indivíduo encontra para manifestar-se, estão as novas formas religiosas. "Elas desenvolvem uma devoção interior [...] o exame de consciência, sob a forma católica da confissão ou a puritana do diário íntimo. Entre os laicos, a oração, cada vez mais, assume a forma da manifestação solitária num oratório privado ou simplesmente num canto do quarto, num móvel adaptado para esse fim, o genuflexório" (1981, p. 10). O homem sente-se livre até mesmo para cultuar. $\mathrm{O}$ rito universal praticado em um espaço público para a manifestação da fé passa a conviver com outras formas de crença e oração. O indivíduo passa a escolher, mais que isso, a própria religião. Se não há liberdade, ele a reivindica. Em outras palavras, a expressão da fé vem plena da vontade individual.

Ora, se tudo deve ser feito a partir da vontade do indivíduo, a questão, portanto, para que não se incorra em caos, é regular-lhe a vontade. Isto é, oferecer-lhe um caminho seguro que lhe permita errar o menos possível. Dizendo de outro modo, trata-se de encontrar regras para que a razão seja soberana.

No plano da formação, coloca-se como tarefa a transformação dos indivíduos a serviço da fé e dos senhores, em pessoas úteis para eles mesmos. Para esse objetivo, o princípio da igualdade torna-se uma bandeira que colocaria fim às seculares diferenças de nascimento, quando os indivíduos tornar-se-iam iguais, não mais porque eram pecadores, mas porque compreenderiam a "individualidade em sua própria pessoa" (LOCKE, 1983, p. 45). Todavia, essa individualidade precisava ser trabalhada. Em uma palavra, disciplinada segundo outro modelo. Esse será um modelo público, cuja regra de conduta deixa o caráter particular, passando pelos grupos associados até chegar ao Estado, que se apresenta como vigilante e protetor de todos os indivíduos e seus bens.

Para a constituição dessa nova ordem um novo homem precisava ser formado e, para esse fim, a escola é chamada, constituindo-se em um dos

ambientes em que se organiza e se difunde aquela civilização das boas maneiras que vem realizar um tipo de sujeito humano bastante diferente do medieval: menos 'natural' e mais 'social', mais constituído 
de normas, de interdições, e transferências, que vêm reduzir, ao lado dos comportamentos, a identidade, tornando-a cada vez mais dependente da sociedade civil. Trata-se de normas e interdições que dizem respeito ao corpo, à linguagem, ao discurso, às relações sociais etc., que negam odores, referências a partes do corpo, a funções, que impõem ritos e cerimônias, utensílios de uso cotidiano (como ocorrerá depois com o garfo), praxes sociais de reconhecimento (saudações etc.) e que a partir da sociedade de corte penetram na sociedade civil: a escola, com suas regras e suas proibições, com sua identidade disciplinar, também colabora intimamente com este processo. (CAMBI, 1999, p. 307)

Note-se, pois, que os espaços formativos do homem ampliam-se. Eles não são mais fechados nos conventos, seminários ou em uma cidade fortificada. A vida urbana, que renasce, promove a abertura da cidade propiciando uma freqüentação maior - embora não seja para todos - a tudo que ela oferecia, como as manifestações culturais e políticas, ao lado das manifestações religiosas. Há, no conjunto da sociedade, um grande esforço para transformar aquele velho homem - escravo, servo, cheio de superstições - em indivíduo, condição só possível pelo processo de formação. Uma formação, entretanto, prática, que o torne capaz de encenar o roteiro que lhe dê a maior vantagem individual. No projeto dele, nada deve lhe atrapalhar: nem Reis, nem Papas, nem Estados. Nenhuma relação pessoal, para ele só o palco da impessoalidade, do "frio interesse do pagamento à vista", dirá Marx (198X, p. 23) mais tarde.

\section{ABSTRACT}

This paper shows the different understandings of the process of formation which the court and bourgeois societies produce. It starts from the principle that the basics of pedagogic modernity are constituted in the court society. In terms of education, the bourgeois relations changed the personal presuppositions of regard, esteem and consideration for the hierarchically superior, to the impersonality, characteristic of its constitutive principles.

Key-words: education; court society; bourgeois society. 


\section{NOTAS}

1. Referindo-se à liberdade que está se construindo especialmente a partir do século XV, Milton Santos afirma que se trata da liberdade "para ser [...] os artesãos, o pedreiro, o alfaiate, mas também os comerciantes" (1982, p. 52).

2. O intervalo que vai da Antigüidade Clássica ao século XVI foi atribuído, $a$ posteriori, como Idade Média. Portanto, um tempo intermediário, um hiato. “Admirador dos clássicos, o italiano Petrarca (1304-1374) já se referira ao período anterior como de tenebrae: nascia o mito historiográfico de Idade das Trevas. Em 1469, o bispo Giovanni Andrea, bibliotecário papal, falava em media tempestas, literalmente "tempo médio", mas também com o sentido figurado de "flagelo", "ruína". A idéia se enraizou quando, em meados do século XVI, Vasari, em uma obra biográfica de grandes artistas do seu tempo, popularizou o termo Renascimento. Assim, por contraste, difundiram-se em relação à fase anterior as expressões media aetas, media antiquitas e media tempora (Franco Junior, H. A Idade Média: nascimento do Ocidente. São Paulo: Brasiliense, 1988, p. 17-18). A simples definição do termo Renascimento já traz todo um preconceito. Portanto, na Idade Média, tudo que não fosse manifestação religiosa estava morto: da cultura ao comércio. Daí o Renascimento, ou seja, movimento que faz reviver tudo o que ultrapassa e, em certos casos, supera os limites do dogma de fé. Contra esse preconceito há que se notar o lugar de onde se fala. "O universo em que estamos mergulhados desde o nosso nascimento não é apenas o da sensação, também é definido pela representação dele que nossa época e nosso meio tendem a nos impor. O homem do século XX não nasce no mesmo mundo que o homem do século XII, e nascer no século XII cristão ou no século XII hindu era nascer em dois universos diferentes. Por mais livre que possa ser um pensamento filosófico e por mais profunda que deva ser a marca por ele deixada na superfície das coisas, ele sempre começa, pois, por um ato de submissão; ele se move livremente, mas dentro de um mundo dado" (GILson, E. A filosofia na Idade Média. Trad. de Eduardo Brandão. São Paulo: Martins Fontes, 1995, p. 941 e 942). Ora, desejar que o movimento não seja possibilitado pelo mundo dado é desejar que uma força venha de fora e diga ou apresente o caminho. Nesse caso, nada mais digno de expressão do dogma de fé.

3. Cf. Comênius. A didática magna. Trad. de Ivone Castilho Benedetti. São Paulo: Martins Fontes, 1977, cap. 19.

4. Opera-se na modernidade um conjunto de mudanças no que se refere aos bens culturais. A esse respeito, cf., em especial, a apresentação ao tema "As formas de privatização" de autoria de R. Chartier (História da vida privada, 3: da Renascença ao Século das Luzes. Trad. de Hildegard Feist. São Paulo: Companhia das Letras, 1991, p. 165). Ao antecipar os subtemas elaborados 
por diversos autores, Chartrier afirma que eles valem-se das anotações de P. Ariès. "De acordo com ele, seis categorias essenciais deviam permitir a identificação das modificações ocorridas no pensamento e na conduta: a civilidade, que suscita atitudes novas com relação ao corpo; o autoconhecimento, procurado na escritura íntima; a solidão, praticada não mais apenas como ascese, porém ainda como prazer; a amizade, cultivada em particular; o gosto, valorizado como uma forma de auto-apresentação; e a comodidade, resultado da reorganização do cotidiano. [...] Entre os séculos XVI e XVIII, o processo de privatização que caracteriza as sociedades ocidentais inclui expectativas e práticas novas, produz espaços, objetos, escritos até então desconhecidos, cria uma inédita consciência de si mesmo e dos outros" (Ibid.).

5. Cf. Teixeira, Lívio. Ensaio sobre a moral de Descartes. São Paulo: Brasiliense, 1990 , p. 23 e 41.

6. Bacon estabelece caminhos empíricos para demonstrar os seus objetivos. A primeira é a presença: "fazer uma citação perante o intelecto de todas as instâncias conhecidas que concordam com uma mesma natureza, mesmo que se encontrem em matérias dessemelhantes. [...] sem especulações prematuras ou qualquer requinte demasiado" (BACON, F. Novum organum. São Paulo: Abril, 1979, p. 14). A segunda é a ausência: "fazer uma citação perante o intelecto de todas as instâncias privadas da natureza dada. [...] É necessário que se limite o reconhecimento das instâncias negativas em correspondência com as positivas e considerem-se as privações apenas naqueles objetos muito semelhantes a aqueles em que elas estão presentes e são manifestas". (Ibid.) A terceira é a comparação: "É necessário fazer-se citações perante o intelecto das instâncias cuja natureza, quando investiga, está presente em mais ou menos, seja depois de ter feito comparações do aumento e da diminuição em um mesmo objeto, seja depois de ter feito comparação em objetos diversos" (Ibid.).

7. Norbert Elias, para definir sociedade e indivíduo, questiona: o social existe para agradar os indivíduos ou estes existem para comporem um todo (fim) social? Por trás dessas duas questões há um princípio: o individualista pensará que o todo existe para o indivíduo; enquanto os defensores do social defenderão que o indivíduo compõe um todo harmônico (que tende ao social). A solução, segundo N. Elias, estaria no equilíbrio, coisa que em nossas sociedades isso não tem deixado o plano ideal. "Ao pensarmos calmamente no assunto, logo se evidencia que as duas coisas só são possíveis juntas: só pode haver uma vida comunitária mais livre de perturbações e tensões se todos os indivíduos dentro dela gozarem de satisfação suficiente; e só pode haver uma existência individual mais satisfatória se a estrutura social pertinente for mais livre de tensão, perturbação e conflito. A dificuldade 
parece estar em que, nas ordens sociais que se nos apresentam, uma das duas coisas sempre leva a pior. [...] Deve-se começar pensando na estrutura do todo para se compreender a forma das partes individuais. Esses e muitos outros fenômenos têm uma coisa em comum, por mais diferentes que sejam em todos os outros aspectos: para compreendê-los, é necessário desistir de pensar em termos de substâncias isoladas únicas e começar a pensar em termos de relações e funções. E nosso pensamento só fica plenamente instrumentado para compreender nossa experiência social depois de fazermos essa troca" (Elias, N. A sociedade dos indivíduos. Trad. de Vera Ribeiro. Rio de Janeiro: Zahar, 1994, p.17-25).

8. A necessidade de um poder regulador central foi defendida por Hobbes que afirmava que os homens trazem originalmente o desacordo entre eles. Esse desacordo é fundado em três princípios: a competição, a discórdia e a glória. A esse respeito diz ele: "A primeira leva os homens a atacar os outros tendo em vista o lucro; a segunda, a segurança; e a terceira, a reputação. Os primeiros usam a violência para se tornarem senhores das pessoas, mulheres, filhos e rebanhos dos outros homens; os segundos, para defendê-los; e os terceiros por ninharias, como uma palavra, um sorriso, uma diferença de opinião, e qualquer outro sinal de desprezo, quer seja diretamente dirigido a suas pessoas, quer indiretamente a seus parentes, seus amigos, sua nação, sua profissão ou seu nome" (HоввEs, T. Leviatã. São Paulo: Abril Cultural, 1979, p. 75).

\section{REFERÊNCIAS}

ARIÈS, P. Por uma história da vida privada. In: ARIÈS, P.; DUBY, G. (Orgs.). História da vida privada. Trad. de Hildegard Feist. São Paulo: Companhia das Letras, 1981.

BACON, F. Novum organum. Trad. de José Aloysio Reis de Andrade. São Paulo: Abril Cultural, 1979.

CAMBI, F. História da pedagogia. Trad. de Álvaro Lorencine. São Paulo: Editora da Unesp, 1999.

CHARTIER, R. História da vida privada: da Renascença ao Século das Luzes. Trad. de Hildegard Feist. V. 3. São Paulo: Companhia das Letras, 1991.

COMÊNIUS. A didática magna. Trad. de Ivone Castilho Benedetti. São Paulo: Martins Fontes, 1977.

DESCARTES, R. Discurso do método. Trad. de J. Guinsburg e Bento Prado Júnior. Porto Alegre: Difel, 1962. 
DUBY, G. A Europa na Idade Média. Trad. de Antônio de Pádua Danesi. São Paulo: Martins Fontes, 1988.

ELIAS, N. A sociedade de corte. Trad. de Pedro Süssekind. Rio de Janeiro: Zahar, 2001.

Zahar, 1994.

A sociedade dos indivíduos. Trad. de Vera Ribeiro. Rio de Janeiro:

FRANCO JÚNIOR, H. A Idade Média: nascimento do Ocidente. São Paulo: Brasiliense, 1988.

GILSON, E. A filosofia na Idade Média. Trad. de Eduardo Brandão. São Paulo: Martins Fontes, 1995.

HOBBES, T. Leviatã. Trad. de João Paulo Monteiro e Maria Beatriz Nizza da Silva. São Paulo: Abril Cultural, 1979.

LOCKE, J. Segundo sobre o governo. Trad. de Anoar Aiex e E. Jacy Monteiro. São Paulo: Abril Cultural, 1983.

MARX, K. Manifesto do Partido Comunista. In: Obras Escolhidas. São Paulo: Alfa-Ômega, 1988.

RIBEIRO, R. J. A etiqueta no Antigo Regime. São Paulo: Moderna, 1999.

SANTOS, M. Metamorfose do espaço habitado. Rio de Janeiro: Hucitec, 1982.

TEIXEIRA, L. Ensaio sobre a moral de Descartes. São Paulo: Brasiliense, 1990. 